Article

\title{
Women's Experimental Filmmaking in Poland in the 1970s and Early 1980s
}




\section{ABSTRACT}

In my article I concentrate on works by three female artists - Natalia LL, Ewa Partum and Teresa Tyszkiewicz. Natalia LL and Ewa Partum started their careers inspired by conceptual tradition, later they extended their interests to feminist concepts, including the image of women, the position of women in a patriarchal society, and the woman as an object to be consumed. Teresa Tyszkiewicz began her artistic activity a decade later; thus, the reflexes of the conceptual trend are less visible in her films than in the works of LL and Partum. Her films can be described as symbolic, dedicated to corporeality and sensuality. Unlike LL and Partum, Tyszkiewicz did not consider her works to be connected to feminism or examples of women's art.

\section{INTRODUCTION}

The art historian Ewa Toniak concludes her article on the situation of female artists in the Polish People's Republic in a very concise way: "It seems that what the Polish [women] artists have had in common is disappearance' (Toniak 2011a: 110). She briefly analysed several cases of artists who were marginalised and forgotten in the art scene of their time or/and later in art history only because of their gender. Maria Hussakowska poses a similar question: "What is the Gender of Polish Conceptual Art?' and shows to what extent many female artists were denied their role in the art processes of the 1970s and for many years also in the art history discourse, which was shaped by a 'masculine' and 'universal' perspective (Hussakowska 2012). Those texts are a result of the recent scholarship that signals the shift toward the re-evaluation of Polish art and the presence of female artists. This approach has been enhanced by important exhibitions, which included Ewa Partum and Natalia LL among others, which have taken place in the past few years. However, as Toniak declares elsewhere, "the process of the reconstruction of women's art in Poland is not a closed chapter' (Toniak 2011b: 10).
The situation is not much different in the field of avant-garde film. The Polish avant-garde cinema of the early 1970s was - similarly to the West - dominated by conceptual trends that took the form of structural film. P. Adams Sitney (1969) defined structural film as a specific stance toward the film medium, based on the exploration of its nature or properties. He also listed four characteristic features (fixed camera, flicker effect, loop printing, rephotography) but said that not every structural film had to include any of them.

In Poland conceptual ideas influenced the practice of Warsztat Formy Filmowej - Film Form Workshop (FFW) - among others. The FFW was a group of students and graduates of the State Film, Television and Theatre School in Łódź (Józef Robakowski, Wojciech Bruszewski, Ryszard Waśko, Paweł Kwiek, Zbigniew Rybczyński, Kazimierz Bendkowski, Antoni Mikołajczyk, Andrzej Różycki, among others), which was formed in 1970 and took interest in nonmainstream, experimental filmmaking. They were active in the field of film, as well as photography, TV transmissions, video art, artistic interventions, etc. A fragment of the FFW's Manifesto summarises the group's attitude and objectives: 
Seeing this kind of perspective before us, we undertake the parascientific activity, cool and calculated artistic theory-practice

1. Entering the sphere of mechanical means of transmission ... we reject all attempts to annex a part of this sphere to serve word culture. More precisely, we reject literary cinema.

2. We also reject all other functions taken from outside the essence of cinema, that is: Politicising Moralising Aestheticising and amusing the spectator.

3. We reject all that disables the breaking the tradition. That hinders the construction of a different picture of reality from the one imposed through school and education.

We reject the film language limited by strict codification and defined utility functions. We pay as much attention to the technical equipment as to the clear channel unblurred by external accretion. Our essential activity is thus unlearning everything produced by education and what we call the found culture.

4. Recognising that reality is received on the basis of transmission, we undertake its examination through the analysis of how the means of our contact with it function. ('Workshop Manifesto' [1975] 2014)

Criticising the dominant, expressive or subjective trends in cinema, the FFW declared its belief in 'pure cinema' and interest in examining the possibilities of the film medium itself. The films produced by the FFW prove this approach. In Market Square (Rynek, 1970) Józef Robakowski, Tadeusz Junak and Ryszard Meissner, by means of time-lapse photography, study the possibilities of the camera as a record- ing device, as well as the construction of filmic time. In Test 2 (1970), attacking the viewer with strokes of flashing light, Robakowski explores the film strip and perception mechanisms. Wojciech Bruszewski's YYAA (1973), a careful study of relationships between sound and image, experiments with filmic time and illusion, created by the vehicle of editing. In Robakowski's I Am Going (Ide, 1973) the author records climbing up the stairs of an observation tower with a handheld camera in one take, while counting out loud. The camera is heavy, we can hear the growing tiredness in the artist's voice but we cannot see his face. Contrary to radical structural film practice, Robakowski reveals the personal, human aspects of film production, which is not exceptional in the works of the FFW. Therefore, in the context of the FFW, Ryszard W. Kluszczyński uses the term 'analytical', coined to highlight the difference between two approaches - the radical stance of the highly depersonalised structural film and a less radical one that is still interested in analysing the film medium (Kluszczyński 1999: 50-65; on the FFW also see Kluszczyński 2014).

The FFW is undoubtedly the most famous and most frequently described phenomenon in Polish avant-garde film of the 1970s (partly due to their presence on the international art scene). Unfortunately, too often the concentration on its oeuvre makes it difficult to see other interesting phenomena. However, in recent years, a wider array of works and practices, underrepresented in the critical discourse to date, has been shown and analysed.

In this article, I take a closer look at the films of three women artists: Ewa Partum, Natalia LL and Teresa Tyszkiewicz. I will argue that their films formed different responses to the situation of women and feminist ideas; responses based on the individual understanding of the transformations of contemporary art and of the social situation of women in Poland. landscape film that combined an analytical stance with the pleasure of representation. 
These artists were not the only women active in the field of experimental filmmaking in Poland in the 1970s. Jolanta Marcolla or Janina Singer, for example, also worked on the avant-garde scene at that time. Works by Partum, LL and Tyszkiewicz were often described using the term 'women's art', sometimes they were even defined as 'feminist'. It is important to note here that there was no feminist movement in Poland in the 1970 s or 1980 s, although some feminist ideas were present in the discourse. That is why I prefer to call Partum's and LL's works 'proto-feminist' - their authors were, to some extent, familiar with Western feminist art or feminist concepts. They also declared their interest in this field and took part in exhibitions of women's/feminist art, and LL even organised the exhibition Feminist Art in 1978. ${ }^{2}$ Agata Jakubowska states that, in case of Partum, LL and Maria Pinińska-Bereś, 'feminism is a derivative phenomenon, coming from outside, from the West' (Toniak 2011 b: 9). ${ }^{3}$

The situation of women in Poland was different from the situation of women in Western countries. ${ }^{4}$ For example, one of the crucial problems raised by the second wave of feminism - the right to abortion - did not affect Polish women, because abortion had been practically legal on request (strictly speaking, on social grounds) since 1956. The Polish People's Republic as a socialist state declared equal rights for men and women, but in practice the equality was only an illusion. Everyday reality differed from the official declarations - the society

2 The exhibition presented the works of Carolee Schneeman, Suzy Lake, Noemi Maidan and LL.

3 Commenting on the situation at the turn of 1960 s and 1970 s, Jakubowska also notes: 'It was precisely the specificity of the situation of women artists in communist Poland (and other countries of so-called "Eastern Bloc") that no coalitions of artists, critics, art historians or curators were formed on behalf of feminist art. If feminist practices were attempted at all, they were not collaborative but individual, separate' (Jakubowska 2011: 25). Toniak (2011b) claims that the exhibitions of women's art in Poland as a phenomenon started in the late 1970s.

4 It also differed from the situation of women (and, on the other hand, the art scene) in other Eastern Bloc countries - even though the political system seemed to be the same, there were crucial differences in various areas of everyday life, as well as in the degree of artistic freedom. at that time remained strongly patriarchal and under the influence of Catholic doctrine. Women had to fill the traditional roles of wives and mothers, which had to be combined with their professional activities. ${ }^{5}$ Piotr Piotrowski has highlighted the fact that this political system had added its own 'limitations of political, social and cultural emancipation of women' to these typically patriarchal restrictions (Piotrowski 2005: 368). ${ }^{6}$

It is not surprising that Partum, LL or Tyszkiewicz - along with other female filmmakers - are often omitted in the presentations of Polish avant-garde cinema. Partum and $L L$ were scarcely mentioned in the first English-language book on Polish experimental film, only in Michael O'Pray's short piece, '1980s: Introduction' (O'Pray 2014: 137). Małgorzata Jankowska (2002) devoted a chapter 'Film and Feminism in Works of Polish Women Artists' of her book on Polish artists' film to the works of Partum, LL and Tyszkiewicz in the context of feminist art. Some of their works were shown in different sections of perhaps the most important exhibition of Polish avant-garde film to date - 1, 2, 3... Avant-Gardes ${ }^{7}$ - but the project lacked any recognition of the relationship of their films to the women's situation. ${ }^{8}$ The compilation Polish Women Artists of the 1970s by the Museum of Modern Art's programme Filmoteka Muzeum is a rare exam-

The situation of women during socialism was the subject of research at an international Women's Memory project (http://www.womensmemory.net/). It resulted, among others, in a documentary video by Sanja Iveković, Pines and Fir Trees: Women's Memories of Life During Socialism (Croatia, 2002) that dealt with the problems of women in the former Yugoslavia and was produced as a part of Women's Memories of Life under Socialism (1998-2004, Center for Women's Studies, Zagreb).

$6 \quad$ It also had its consequences in art - Piotrowski suggested that it was the reason why women were unlikely to produce works in the field of body art.

$7 \quad$ 1,2, 3... Avant-Gardes: Film/Art between Experiment and Archive, curated by Łukasz Ronduda and Florian Zeyfang, presented in the Center for Contemporary Art Ujazdowski Castle in Warsaw, Künstlerhaus Stuttgart and Sala de Rekalde in Bilbao in 2007-2008.

8 For example, the only film by Partum, Drawing TV (1976), was presented in the section Analytical Cinema, which reduced the meaning of Partum's work to its conceptual positions. Nonetheless, this exhibition is important due to the new perspectives of reading experimental film of the 1970s, which until then was mostly presented as a conceptual (analytical) phenomenon. 
ple of presenting women's works together. Nevertheless, it simply combines films made by women based only on the gender of the authors.

\section{'MY PROBLEM IS THE PROBLEM OF A WOMAN': EWA PARTUM}

Ewa Partum, a pioneer of both conceptual and feminist art, graduated from the Academy of Fine Arts in Warsaw. The founder of Adres Gallery, she has been active in the fields of visual poetry, performance art, photography, film and - last not least - mail art. Partum has been particularly interested in the situation of women in art. In one of her actions she stated that 'the artist has no biography' - but this applies only to male artists. ${ }^{9}$ Female artists certainly do have a biography - if we take a closer look at art criticism, we will quickly notice the importance of how old the female artists are, how they look, and who they are married to. Toniak describes the attitudes of the art world toward women in such categories - she says that the critics tended to elaborate not only on the works of art created by women, but also on the look of their authors. Women were often given the role of a beautiful object, of a wife of an influential artist (Toniak 2011a: 102-103), or, perhaps, of a person who manages the art scene (Hussakowska 2012: 37-38).

Partum was obviously conscious of these mechanisms. She declared that her problem 'is the problem of a woman'. In the action called Change (1974) she had half her body treated with make-up to make it look older and highlight how she, as a woman, functioned in the art world; it recalls the famous statement from the classical performance piece by Marina Abramović - 'Art must be beautiful. Artist must be beautiful'. The feminist intuition and tendency to analyse the situation of women in a patriarchal world have been present in Partum's works from the very beginning of her career; but it was only in the late 1970s that she openly declared an interest in feminism. Simultaneously, she was describing herself as a conceptual artist.

Andrzej Turowski speaks about Partum's 'feminist conceptualism' (Turowski 2013); Aneta Szyłak, the curator of Partum's 2006 solo exhibition in Gdańsk, underlines the tension between conceptual ideas and their indifference to gender (or considering an artist as masculine) and the feminist recognition of women's situation in the world (and, I should add, the world of art) ${ }^{10}$ (Szyłak 2013). Agata Jakubowska analyses the combination of conceptualism and feminism in Partum's work in terms of the 'impossibility of understanding', considering the feminist elements of the artist's approach to art primarily as a result of her conceptual interests in communication. Jakubowska writes:
Partum cares primarily about being the subject of discourse and concentrates on what makes it difficult, or impossible, for her. However, she is particu- larly interested in the exclusion (oppression) of women, not in the repression of the women's voice. Not in the impossibility of expressing women's experience, rather in those elements of the social functioning of women that lead to silencing them. That lead to silencing her, marginalising her. (Jakubowska 2006)

This aspect of Partum's activity is clearly visible when we consider her films of the 1970s. She made only a few films, deeply rooted in the conceptual trends of the time, gathered in Tautological Cinema Kino

10 In the same book, Luiza Nader comments on Partum's position in Polish art history: 'Partum after all introduces into the experience of conceptualism the notion of Difference... The repeated efforts to exclude Partum from conceptualism or the reverse, namely, the repression of conceptual aspects in Ewa Partum's work should be, I believe, considered as a desire expressed by the researchers for definitional certainty and a repetition of the binary oppositions binding in the 1970s: body/mind, image/text, idea/thing, art investigating abstract structures/politically committed art, avantgarde/pseudo-avantgarde' (Nader 2013:32). 
Tautologiczne, 1973-1974). The collection consists of several short films, minimalist in form. As formal experiments, these films are typical examples of the conceptual trend. Partum did not create a symbolic environment or try to tell a story, but explored the possibilities of the medium. In a statement that accompanies the film she wrote:

The problem of the autothematism of transmission.

A deliberation on the sense of the existence of the film as a medium, its semantic structure of objectivism and relativism.

The reduction of conventionally used means, departure from literary issues, and operation performed on meanings.

This is not

dealing with aesthetics, this is

a new kind of philosophical practice

in an area where relations

between the film image and the movement of the camera exhaust the range of interest in the reality of film.

This ensues from the problem of the film as an idea and the capacities of film structure

as a medium

and this constitutes its only content and is its only meaning. Art that is internally filmic up to the exhaustion of the potential of the cinema

as a semantic medium. ('Works'

2013: 233)

Partum uses fixed camera, sometimes experiments with zoom or lighting to show how the film medium works. For instance, she explores the projection mechanism, physicality of the film strip and the relations between filmic time and projection time. The piece lasts as long as it takes to project ten metres of the film; every metre is indicated by an intertitle: '1 metre', '2 metres', etc.
However, the conceptual paradigm does not describe the aspects of the films that seem to anticipate the feminist concepts analysed by Partum in her later works. In one of the pieces of Tautological Cinema, Partum hides her eyes, her ears and her lips - she shows that she cannot see, hear or speak. We may interpret this gesture as a symbolic way to show how women are deprived of their voice or how they are being made invisible. In the end, however, Partum covers her face with her long hair - her face is no longer visible due to a stereotypically feminine attribute, and therefore makes the emerging feminist intuition ${ }^{11}$ much more complex and open. In another piece Partum uses acacia leaves she rips one leaf after another. The camera slowly moves and shows the intertitle 'etc..' This action could be interpreted as just another way of measuring time and analysing relations between the time of the filmed reality and the time of the projection. Such an interpretation would omit the symbolic value added to the action with the choice of the 'tool' of measurement. Acacia leaves are commonly used in children's plays when young girls try to 'predict' whether he 'loves me or loves me not'; the use of a sign of girls' patriarchal upbringing obviously colours the meaning of the film.

Finally, Tautological Cinema gives viewers the famous declaration: "My touch is a touch of a woman'. Partum uses a lipstick imprint as her personal signature.12 This gesture can be interpreted as a socio-political commentary, especially when we note that many Polish conceptual artists (among others in Eastern Bloc) tended to avoid any notion of political art because of the overwhelming association with the period of social realism (Piotrowski 2005). Andrzej Turowski, commenting on the differences between the conceptual ideas in Poland and the West, notices that "the highlighting of sexual difference in the Communist world

In the interview from 2006, Partum claimed that the feminist interpretation was added; see Jarecka 2006.

12 Partum started a fierce discussion about The Love Project by Iwona Majdan, a Canadian artist who also used images of lips; see Jakubowska 2006. 
of "equal rights", being a demand for recognition of that difference, called the whole ideological order into doubt' (Turowski 2013: 52). The ideological order was founded on a certain image of the body; Turowski states that

the official policy related to the body throughout the entire post-war history of Poland has been attempting to shape corporeality on the model of an androgynous phantasm which, deprived of gender, took the male form of the Proletarian (in practice, and particularly in the consumerist years of the Gierek era, this ideal became watered down on the covers of Ty $i J a$ ). (Turowski 2013: 52)

By making the sexual difference visible and making it central to her work, Partum revealed the façade of the political system. The meaning of this gesture would be emphasised when we considered the critical stance toward gender stereotypes. Later Partum would analyse the oppressive institutions of the patriarchal society, like marriage, which, according to the artist (Jarecka 2006), seemed to be the only possible choice for girls in Poland of the 1960s and 1970s.

This personal signature is worth a closer reading. Lips, as Jakubowska suggests, are a feminine attribute, associated with sexual pleasure but do not refer to the woman's needs or desires; a sign of the patriarchal repression of the subordinate woman who is treated as a sexual object (Jakubowska 2004: 102).13 Given the interpretation, the choice to use such a signature could not be seen as neutral. Partum clashes the image of her lips with letters - the images are not understandable without the elements of the code. Perhaps we should say - a patriarchal code - imposing order on the world, defining its meanings. loop-printing, a young, attractive and smiling woman blows a kiss at a viewer several times. Again, the author combines a stereotypically feminine gesture with an analytical stance of a filmmaker.
The often analysed opposition between nature and culture (and respectively between female and male) is obviously at work here.

Partum's concept may seem similar to the idea that Martha Rosler presented in her Semiotics of the Kitchen (USA, 1975) when she structured her work around the alphabet as an arbitrary code imposing order and meaning on the world. Partum has also declared her position as the position of a woman. She is a female author - and at the same time she is a conceptual author exploring the means of art. Tautological Cinema can be regarded as a typical example of analytical cinema - but it is the analytical cinema made from a female position.

This position becomes less obvious when we turn to Drawing TV (1976). Partum draws on the television screen which she re-films. ${ }^{14}$ Sometimes we see only the 'dirt' behind the drawings - electronic noise resulting from interferences. However, mostly we can see typical examples of television of the late 1970s - news, debates, all visibly peppered with propaganda. Łukasz Ronduda (2013: 68) reads Partum's gesture in terms of political intervention; this interpretation seems legitimate if we recall the socio-political background of socialist Poland in the late 1970s, marked by social protests and the formation of anti-communist civil resistance.

In Active Poetry. Poem by Ewa (19711973), Partum refers to her long-lasting practice in the field that could be called visual poetry. She produced several works utilising the specific notion of poetry as an aleatory activity, giving the reader/viewer the possibility to co-create it. For instance, she put letters cut from paper in places where the members of the audience might accidentally take them along - on their

\footnotetext{
14 It is also worth noting that Partum typically uses the structural technique of re-filming. She films television screen with a film camera, which gives - as Ronduda (2013) notes - a characteristic quality to the image, resulting from the difference in frame rate in film camera and on television. It adds a transmedia quality to the work, especially when we consider the way the drawings correspond to the nature of TV interruptions (Jankowska 2002: 142).
} 
shoes, etc. In the film, Partum documents her actions - we can see the artist throwing the letters into the wind or water. The film reuses the aforementioned opposition between nature and culture, but this time the element of culture, the alphabet, is shown as being prone to the influence of accident or nature. Here, nature seems to be an active or even dominant element, ${ }^{15}$ as Partum frees the letters of cultural rules (which are implicated by the image of a dictionary) that can easily be read as masculine rules.

\section{'ART IS A STRUCTURE THAT ALLOWS PARADOXICAL OPERA- TIONS': NATALIA LL}

Natalia $L L$ is the artistic pseudonym of Natalia Lach-Lachowicz. She graduated from the Academy of Fine Arts in Wroctaw and has been active in the fields of photography, film and video and performance art; in the 1970s she co-founded the PERMAFO Gallery in Wroctaw. Her pseudonym was created in an interesting way - Natalia did not simply reject the names of her father and her husband, but abbreviated them, choosing to use only the initials, as if she simultaneously wanted to construct her own identity and not lose touch with the existing circumstances. In her statements she often used only her first name, Natalia, in contrast to the last names of the male artists she is referring to. This gesture can be interpreted in feminist terms; and it has certainly been interpreted as such by the feminist artists and critics who contacted Natalia as a feminist artist. LL took part in several events as an 'agent' - as she calls it - of the feminist movement in this part of Europe (Jurecki 2004); her works were presented and interpreted in a feminist perspective. ${ }^{16}$ In subsequent years the personal elements in her works became more and more intensively present, dominating

It is tempting to draw a parallel with works of Maya Deren or Carolee Schneemann, the great female artists who also worked with the symbolic meaning of water as a feminine element.

16 Toniak, quoting Jakubowska, suggests that LL's works should be read in terms of " appropriation" by the Western feminist discourse' (Toniak 2011a: 90). the conceptual stance. Her works from the 1980 s and 1990 s refer to the mythical, archetypal dimensions of life, and explore such universal topics as dreaming, change and death. Around that time she also rejected feminism, talking about its 'xenophobia' (LL [1991] 2005: 375).17

Let us concentrate on LL's works from the 1970s. Her films from that period are the result of her approach to art in general; the film medium was just another tool to explore the possibilities and limitations of art. Of course, the conceptual inspirations are clearly visible, but, as Jan Świdziński ([1975] 2004) has explained, her works go far beyond any conceptual limitations. Świdziński described three stages of contemporary art: 'dematerialization', 'analysis' and 'grammaticalization'. The first is connected to the 'ultimate exhaustion of expressiveness in traditional art', the second is 'an analysis of the function of art' (Świdziński [1975] 2004:302). The last stage, which is exemplified by LL's work, 'suggests the possibility of creating a new grammar of art after the period of conceptual analyses' (Świdziński [1975] 2004:303).

LL produced several works based on the 'permanent record', filming different objects or places (a clock, a motorway) at certain time intervals, in the films Permanent Measurement of Time (Rejestracja permanentna czasu, 1970) and Permanent Measurement of Every $1 \mathrm{~km}$ of the E22 Motorway (Rejestracja permanentna co $1 \mathrm{~km}$ autostrady E22, 1970). This bears a resemblance to the structural practices of analysing the construction of filmic time and space or the relationships between real time and screen time. LL explained her attitude toward recording the elements of everyday life (not only in the context of these films):

Art is in the process of becoming in every instant of reality: to

There is a striking contrast between LL's views expressed in the 1970s and later; compare her lecture The Feminist Tendency at a symposium on photography in 1977 (LL [1977] 2004) and an interview given in 2001-2002 (Jurecki 2004). 
the individual every fact, every second is fleeting and unique. That is why I record common and trivial events like eating, sleeping, copulation, resting, speaking etc. Moreover, each activity of a man being a component of his reality is absolutely equal in evoking mental reaction in a man who watches the notation. That is why I can transform a registration of one activity into another one. It is not substance and a formal appearance which are essential but an effect, that is, meaning. (LL [1975] 2004: 279)

Perhaps LL's most famous filmic work, however, adds an erotic and corporeal dimension to the aforementioned structural traces. Consumption Art (Sztuka konsumpcyjna, 1975; LL also made a photographic cycle under that title) clearly has its roots in the conceptual analysis of the language of art or functions of the film medium; it even utilises fixed camera, typical for structural filmmaking. Antoni Dzieduszycki comments on the photographs from the Consumption Art cycle:

The actions - as the artist states - are basic, even banal acts, like eating, sleeping, working, uttering words, but their ambiguous meanings become gradually revealed.... The simple act of eating gets transformed into refined eroticism and subsequently into an almost magical gesture, part of the system of signs that belong to some universal but obscure code. This process is not only intriguing in itself but inspires reflexion on signs and codes we employ to communicate. (Dzieduszycki 2004: 283)

The film could be seen as a pure example of analytical cinema, if it was not so clearly erotic.

In LL's film, a topless young girl with make-up and a carefully arranged haircut is seen in a close-up; she is constantly smiling at the camera, eating bananas and sausages. She plays with them: puts them in her mouth and takes them out, licks them (David Crowley [2007: 16] describes it straight-forwardly - "she fellates one thick sausage, then another') and licks her lips; from time to time she lets a dense white liquid flow from her mouth. This overtly erotic behaviour brings to mind pornographic imagery, especially when we consider that we are watching a young, naked woman who is performing her actions in front of a camera, smiling at the viewer. She seems to be a sexual object whose entire screen presence is designed for the pleasure of a male viewer, as the feminist film critics would see it. This reading is reinforced when we realise what happens at the end of the film: 'The climax of this act is not one of consumption on her part: in fact, she is consumed by the apparent appearance of creamy ejaculate in her mouth, following a jerky cut' (Crowley 2007: 16). However, this strategy, typical of film and visual art, is here carefully deconstructed. ${ }^{18}$

Such an interpretation, although tempting, ignores quite a fundamental nuance - that this work was produced in a society in which sexuality was repressed, partly because it was seen to be associated with the 'degenerated' West (and partly, of course, because of the influence of the Catholic tradition). This taboo is, however, not the only element that is lacking. More important, perhaps, is the economic situation - mentioned by Piotrowski or Crowley - that made such unavailable products as bananas or sausages almost a kind of luxury goods. Crowley calls this work 'a com-

It is, however, not obvious for the critics. The authors of the archive section of 1, 2, 3...Avant-Garde note that: 'It has often been stressed that the model in Consumption Art frees herself from the role as an object of erotic contemplation, is autonomous and, similarly to LL's other works, becomes a figure of a woman exploring the realms of her own sexuality. From a passive object of desire she becomes a fully empowered subject' (Jachuła et al. 2007: 148), but it is difficult to agree with such an interpretation. Gislind Nabakowski, commenting on LL's works, has highlighted the way the artist rejects 'two myths' first, the one of the vamp murdering men; secondly, the one of a penis (Nabakowski [1975] 2004). 
mentary on dissatisfaction' (Crowley 2007: 16). Piotrowski argues that LL's critique of consumerism has been ambiguous and, in the socialist Poland of the 1970s, lacking context (Piotrowski 2005: 378). Piotrowski also claims that reading Consumption Art from a feminist perspective reveals the superficiality of the 'equal rights' in the Polish reality and the striking discrepancy between the official declarations or actions and everyday life.

This characteristic mixture of formal minimalism and rigid structure with a focus on the female body is also present in LL's other films from the 1970s. In Impressions (Impresje, 1973), LL shows the female body as an erotic object in a much clearer way. The model, filmed naked most often in close-up focusing on her breasts and abdomen, is again presented in a sexual context - she touches her breasts, a moment later suggestively trembles; in the end, a white, thick liquid flows down her body. The visible fragmentation of the naked female body (chosen by the female artist for her work which refers to the language of art), together with the obvious allusions, can easily be interpreted as taking part in the debate about representation of the female body in art.

Artificial Reality (Sztuczna

rzeczywistość, 1976) also deals with the female body. Although important, it is no longer the central aspect of the film. The woman poses in front of the camera makes gestures, changes positions on the couch, fiddles around the flat. More important than her sometimes naked body is the way the film is edited: LL used superimpositions to create an 'artificial reality' - a reality that results from putting together two (sometimes only slightly) different images. It is interesting how this tool works as a kind of veil - we cannot see the details of the model's body because it is hidden behind the filmic technique. ${ }^{19}$ The examination of the medium comes to the fore here, but this examination can only take place when the body - as a kind of a tool - is used.

\section{'MY FILMS ARE THE MOVING IMAGE OF MY EXPERIENCE': TERESA TYSZKIEWICZ}

Teresa Tyszkiewicz, who graduated from the Technical University in Warsaw (contrary to Partum and LL, she was not trained as an artist), made her first films with her husband Zdzisław Sosnowski who has been active in the circle of the PERMAFO Gallery since the early 1970s. Those films, which arose from post-conceptual experiments of the late 1970s, presented the trend that would dominate Polish experimental cinema in the 1980s.

The Polish avant-garde film of the 1980s can be, as Kluszczyński (1998: 30-33) argued, characterised by the term 'pluralism'. This means the pluralism of styles, but also of approaches toward film. After the 1970s, which was dominated by 'medialism', in the 1980s artists often returned to subjective, emotional, expressive filmmaking; the exact approach the FFW criticised in their Manifesto. Of course, this trend was not unique to Poland - in British experimental film and video, for instance, a similar change resulted in the appearance of the 'New Romantics'.

The collaborative films made by Sosnowski and Tyszkiewicz, in which the artists tried to deal with their relationship, obviously arose from their everyday life. Sosnowski and Tyszkiewicz sought to analyse their relationship through intrusively erotic images and symbols (which should be, as I already mentioned when characterising LL's works, understood in the context of the puritan, socialist society of an Eastern Bloc country). In Permament Position (State zajęcie, 1979), they pose in different costumes (or almost naked) and in different circumstances. Tyszkiewicz, whose onscreen presence dominates the film, wears fur, high-heeled shoes, tights - obviously erotic symbols that could be associated with popular images of the West. Permament Position intercuts moving image with frozen film frames - it can be seen as a kind of aftermath of the analytical tendencies. Crowley adds another aspect in his interpretation: 'The screen flicks between black 
and white film and highly saturated colour still, reminding the viewer of the interrelated codes of fashion photography and pornography' (Crowley 2007: 19).

In The Other Side (Druga strona, 1980), the artists confront their own images with the images on television screen. Re-filmed, they form, in a sense, decorations for the performance of Tyszkiewicz who makes suggestive gestures. The way she demonstrates her legs in a series of poses and exercises is juxtaposed with a different kind of television footage - we notice not only some debates and fragments of films, but a pop music performance or dance as well. Later in the film the artist looks through an illustrated magazine - it seems as if all her actions were constructed from such stereotypical elements. ${ }^{20}$ Then both artists pose together in front of the mirror - the woman wears tights and high-heeled shoes, the man shows his naked, hairy legs. In the end, the camera, in rapid movements, films them lying on the bed.

In this flow of erotic images, we cannot overlook the fact that Tyszkiewicz, as an erotic symbol, uses tights and not stockings. She poses in suggestive ways, as if trying to mimic certain codes, but the realisation is deeply rooted in her everyday life, plagued by the rationing of certain goods. To quote Crowley again, those films form 'a provocative response to what might be called the visual and material culture of "banal socialism"' (Crowley 2007: 19). What is more important, this response can be read in Jean Baudrillard's terms: 'In this peculiar fashion, socialist consumerism was experienced in terms of what Baudrillard famously called the simulacrum, i.e. as an image world where the real was itself yet another kind of image'; later Crowley adds that '[p] recisely because they hardly existed in material terms in the East, Western goods were perfect vehicles for fantasy. They were utopian in a literal sense' (Crowley 2007: 24).

However, these works should not be reduced to a commentary on consumerism Double Life series (1975-1976) by Sanja Iveković. in the socialist reality of ration cards. It is interesting how the image of woman has been constructed here - the female body is fragmented, filmed in close-ups, a choice that clearly depends on the erotic value of the body parts. Tyszkiewicz seems to be a pretty, young model in front of the lens of an experienced photographer - and although she signed those works as co-author, this ambiguity in her performance is hard to reject.

This question will accompany the viewer while watching Tyszkiewicz's own films. She was not a prolific filmmaker; after migrating to Paris in 1982, she concentrated on other artistic activities. Tyszkiewicz did not call her works feminist; she also did not associate them with 'women's art' (Jankowska 2002: 144), although she took part in some exhibitions by female artists. Moreover, her works are sometimes described and interpreted in feminist terms; even Małgorzata Jankowska, who noted Tyszkiewicz's declaration, analysed her works in a chapter on Film and Feminism.

Tyszkiewicz's films are perhaps best described by the concept of exploring femininity. They are characterised with terms such as 'feminine intuition' or 'feminine sensitivity' (Jankowska 2002: 144); they seem to be a typical example of exploring one's own identity. Tyszkiewicz confronts herself with the external world (what can bring to mind the trance films of the early American avant-garde cinema, such as Maya Deren's At Land [USA, 1944]; see Sitney 1974), and does it in a very corporeal way. As the artist herself has declared, "[m]y films are the moving image of my experience, individual image, the way of looking at the world and feeling its existence. They are the process of exploring the creative possibilities, their mystery and inner sense' (Jankowska 2002: 146). Her own films seem a little more subtle and a little less analytical than the productions on which she collaborated with Sosnowski; she has often used the same erotic signs or symbols of stereotypical femininity but the mood is different. The body becomes a tool of gaining self-knowledge. To quote Tyszkiewicz again, 
Objects and materials in contact with my body help me materialise the whole process of my thinking, to discover the inner method of seeking sense on the basis of consciousness or unconscious activity. In the end, those objects dominated by the movement and body action, lose their meaning, move the body-object to the fore, building its psychology and content. (Jankowska 2002: 151)

In films such as Grain (Ziarno, 1980), Breath (Oddech, 1981) and Image and Games (Obraz i gry, 1981), Tyszkiewicz performs a series of activities that can be regarded as quasi-ritualistic - or quasi-absurd. She digs in grain and then in feather, she lays on a meadow playing with a wooden construction, tears some white material, touches a sticky white substance - all to the accompaniment of a strange hypnotic sound track, containing some field recordings, sometimes mixing pop songs or, on the contrary, patriotic melodies or organ music. The scenes are put together according to an associative logic; carefully designed images are filmed without following the rules of mainstream cinema. It is close to oneiric poetics; and similarly to other artists who used it, Tyszkiewicz seems to explore unconscious, uncontrolled, unknown or wild impulses. Such a description is quite close to the concept of nature and femininity; therefore Tyszkiewicz's films can be interpreted as another essentialist view on the so-called 'nature of women'.

Let us analyse two examples. Grain offers the spectator a well-known array of costumes and gestures. In her performance Tyszkiewicz uses grain and feather, and this time parsley roots and beetroots as well. She lies down in the grain, touches the vegetables with her hair; all her actions are subtle and slightly erotic, partly because of the costumes she is wearing. Tights are again an important part of the performance. Tyszkiewicz uses them to create something mannequin-like: she fills them with a substance (perhaps the grain) so as they look like human legs. The rapid editing makes it difficult to take a closer look; Tyszkiewicz poses with these forms, as if she would like to complicate her relationship to the world and her identity.

In Image and Games Tyszkiewicz performs in two different spaces: in an old, perhaps abandoned, building and outside, on a meadow. She tries to drag something under the wooden floor, hammers nails into small pieces of wood, rummages through strange metal and wooden objects, stirs in the sticky liquid. When she glues a magazine to the wall - the magazine appears to be Tygodnik Solidarność (Solidarity Weekly), an independent magazine published by the Independent Self-governing Trade Union Solidarity; we can hear Rota, a Polish patriotic song, which is crucial here. The poem was written in the early 20th century as a protest against the Germanisation that was occurring in the partitions of Poland at that time. Made in the year that Martial Law was declared, the film makes a strong political statement regarding the country's situation. Later the woman, with visible effort, tries to move a large and heavy sack; finally she ties it with a piece of white and red cloth (the colours of the Polish flag). In the end, we see her dressed in red kneeling beside the sack, holding it as if it were part of her body. It seems that the film has moved from the exploration of individual identity to collective identity, rooted in national history and socio-political circumstances and marked by the figure of the Polish Mother - the bearer of the national traditions sacrificing herself for the family. We could extend this interpretation and see the ending as a reflection of the situation of women in these particular circumstances. ${ }^{21}$

2

It is, however, interesting (and at the same time very telling) that the authors, describing the film for the Filmoteka Muzeum, conclude that "[t]he film comes to an end with a feminist-flavoured scene of submission after a failed attempt at revolutionising the stiff manner of perceiving gender and female sexuality' (http://artmuseum.pl/en/filmoteka/praca/tyszkiewiczteresa-obraz-i-gry); such a conclusion is undoubtedly too far-reaching and unjustified. 


\section{CONCLUSION}

All the works analysed in this article can be interpreted in terms of proto-feminist art as a strong woman's voice in Polish experimental filmmaking of the 1970s and 1980s. However, this voice is varied and marked by an individual approach to art. Ewa Partum, Natalia LL and Teresa Tyszkiewicz produced their works from the female perspective.

This could mean a very thorough analysis of the mechanisms of gender discrimination in the art world and everyday life as in Partum's case. It could perhaps be a superficial understanding of feminism in LL's works. And last not least, it could be a confrontation with the external world and finding a female identity, as Tyszkiewicz showed. The artists differ also when it comes to the declaration of feminism: Partum declares herself a feminist; LL once performed as an 'agent' of the feminist movement in Eastern Europe but later rejected the idea; Tyszkiewicz never felt any connection to either feminism or women's art.

Last not least, all three artists worked with the most important ideas in the art scene of their time, reconfiguring them to strengthen their own female voices. Partum and LL, who made their debuts under the influence of conceptualism, tried to combine a female perspective and conceptual ideas. It resulted in Partum's 'feminist conceptualism' and LL's works going beyond the limitations of conceptual art. Tyszkiewicz, who started her artistic career a few years later, chose methods and approaches rejected by conceptualism - she returned to exploring personal, symbolic, subjective filmmaking.

Partum, LL and Tyszkiewicz used the body as one of the most important artistic tools. Partum often performed naked, and she also made photo montages showing her naked in the public places. Her problem is the problem of a woman - and it is deeply rooted in corporeality. LL's focus on the body is a consequence of her conceptual approach to art.22 Tyszkiewicz used her body conceptual art. as a tool to deal with the external world and the inner self. All three artists have tried to re-shape and re-adjust the dominant trends in art so their individual voices could be heard. 


\section{REFERENCES}

Crowley, David 2007. 'The Art of Consumption'. - Łukasz Ronduda, Florian Zeyfang (eds.), 1, 2, 3... Avant-Gardes: Film/Art between Experiment and Archive. Warsaw: Center for Contemporary Art; Berlin: Sternberg Press, 16-27.

Dzieduszycki, Antoni 2004. 'Natalia Lach-Lachowicz'. Trans. Małgorzata Możdżyńska-Nawotka. - Natalia LL (ed.), Natalia LL - Texty. Teksty Natalii LL. O twórczości Natalii LL. Bielsko-Biała: Galeria Bielska BWA, 281-283. Hussakowska, Maria 2012. 'Czy polska sztuka konceptualna ma płeć?' - Sztuka i Dokumentacja 6, 29-39.

Jachuła, Michat; Pawełek, Kaja; Ronduda, Łukasz; Woliński, Michat 2007. 'Archive'. - Łukasz Ronduda, Florian Zeyfang (eds.), 1, 2, 3... Avant-Gardes: Film/Art between Experiment and Archive. Warsaw: Center for Contemporary Art; Berlin: Sternberg Press, 104-155. Jakubowska, Agata 2004. Na marginesach lustra. Ciato kobiece $w$ pracach polskich artystek. Kraków: TAiWPN Universitas.

Jakubowska, Agata 2006. 'Niemożność porozumienia feminizm indywidualny Ewy Partum'. http://www.obieg. pl/teksty/5852 (11 September 2015).

Jakubowska, Agata 2011. 'Lips Wide Shut'. - Ewa Toniak (ed.), Three Women: Maria Pinińska-Bereś, Natalia LL, Ewa Partum. Trans. Marcin Wawrzyńczak. Warszawa: Zachęta Narodowa Galeria Sztuki, 25-38.

Jankowska, Małgorzata 2002. Film artystów. Szkice z historii filmu plastycznego i ruchu fotomedialnego w Polsce w latach 1957-1981. Toruń: Wydawnictwo Uniwersytetu Mikołaja Kopernika.

Jarecka, Dorota 2006. ‘Ewa Partum: artystka performerka. Z Ewą Partum rozmawia Dorota Jarecka'. http://www.wysokieobcasy.pl/wysokieobcasy/1,96856,3539283.html (11 September 2015). Jurecki, Krzysztof 2004. 'Krzysztof Jurecki's Interview with Natalia LL'. Trans. Jarosław Fejdych. - Natalia LL (ed.), Natalia LL - Texty. Teksty Natalii LL. O twórczości Natalii LL. Bielsko-Biała: Galeria Bielska BWA, 480-488. Kluszczyński, Ryszard W. 1998. Obrazy na wolności. Studia z historii sztuk medialnych w Polsce. Warszawa: Instytut Kultury.

Kluszczyński, Ryszard W. 1999. Film. Wideo.

Multimedia. Sztuka ruchomego obrazu w erze

elektronicznej. Warszawa: Instytut Kultury.

Kluszczyński, Ryszard W. 2014. 'The Mechanical Imagination - Creativity of Machines: Film Form Workshop 1979-1977'. - Kamila Kuc, Michael O'Pray (eds.), The Struggle for Form: Perspectives on Polish AvantGarde Film, 1916-1989. London: Wallflower Press, 117-136.

LL, Natalia [1975] 2004. 'Transformative Attitude'. Trans. Henryk Holzhausen. - Natalia LL (ed.), Natalia LL Texty. Teksty Natalii LL. O twórczości Natalii LL. Bielsko-Biała: Galeria Bielska BWA, 279-280.

LL, Natalia [1977] 2004. 'The Feminist Tendency'. Trans. Jarostaw Fejdych. - Natalia LL (ed.), Natalia LL - Texty. Teksty Natalii LL. O twórczości Natalii LL. Bielsko-Biała: Galeria Bielska BWA, 320-324.

LL, Natalia [1991] 2004. 'The Theory of Head'. Trans.

Marek Lasota. - Natalia LL (ed.), Natalia LL - Texty.

Teksty Natalii LL. O twórczości Natalii LL. Bielsko-Biała:

Galeria Bielska BWA, 374-377.

Nabakowski, Gislind [1975] 2004. 'Zwei Mythen werden mit Vergnuegen preisgegeben'. - Natalia LL (ed.),

Natalia LL - Texty. Teksty Natalii LL. O twórczości Natalii LL. Bielsko-Biała: Galeria Bielska BWA, 291-293. Nader, Luiza 2013. 'Conceptual Art and Ewa Partum. Aneta Szyłak, Berenika Partum, Ewa Małgorzata Tatar (eds.), Ewa Partum. Gdańsk: Instytut Sztuki Wyspa, Fundacja Wyspa Progress, 24-36.

O'Pray, Michael 2014. 'The 1980s: Introduction'. -

Kamila Kuc, Michael O'Pray (eds.), The Struggle for Form: Perspectives on Polish Avant-Garde Film, 1916-1989. London: Wallflower Press, 137-138.
Piotrowski, Piotr 2005. Awangarda w cieniu Jatty. Sztuka w Europie Srodkowo-Wschodniej w latach 1945-1989. Poznań: Dom Wydawniczy Rebis.

Ronduda, Łukasz 2013. 'Between Conceptualism and Nominalism: About Ewa Partum's “Tautological Cinema"'. - Aneta Szyłak, Berenika Partum, Ewa Matgorzata Tatar (eds.), Ewa Partum. Gdańsk: Instytut Sztuki Wyspa, Fundacja Wyspa Progress, 60-70. Sitney, P. Adams 1969. 'Structural Film'. - Film Culture 47, 1-10.

Sitney, P. Adams 1974. Visionary Film: The American Avant-Garde. New York: Oxford University Press.

Szyłak, Aneta 2013. 'The Non-Transmittability of the Message: In the Context of the Exhibition and Monograph “Ewa Partum: The Legality of Space"'. - Aneta Szyłak, Berenika Partum, Ewa Małgorzata Tatar (eds.), Ewa Partum. Gdańsk: Instytut Sztuki Wyspa, Fundacja Wyspa Progress, 10-20.

Świdziński, Jan [1975] 2004. 'Grammaticalizations of Natalia LL'. Trans. Jarosław Fejdych. - Natalia LL (ed.), Natalia LL - Texty. Teksty Natalii LL. O twórczości Natalii LL. Bielsko-Biała: Galeria Bielska BWA, 302-304.

Toniak, Ewa 2011a. 'Artystki w PRL-u'. - Agata Jakubowska (ed.), Artystki polskie. Warszawa: Wydawnictwo Szkolne PWN ParkEdukacja, 94-111.

Toniak, Ewa 2011 b. 'Impossible?' - Ewa Toniak (ed.), Three Women: Maria Pinińska-Bereś, Natalia LL, Ewa Partum. Trans. Marcin Wawrzyńczak. Warszawa: Zachęta Narodowa Galeria Sztuki, 4-10.

Turowski, Andrzej 2013. 'The Greatness of Desire: On the Feminist Conceptualism of Ewa Partum in the 1970s'. - Aneta Szyłak, Berenika Partum, Ewa Małgorzata Tatar (eds.), Ewa Partum. Gdańsk: Instytut Sztuki Wyspa, Fundacja Wyspa Progress, 40-56.

'Works' 2013. - Aneta Szyłak, Berenika Partum, Ewa Małgorzata Tatar (eds.), Ewa Partum. Gdańsk: Instytut Sztuki Wyspa, Fundacja Wyspa Progress, 185-340. 'Workshop Manifesto' [1975] 2014. - Kamila Kuc, Michael O'Pray (eds.), The Struggle for Form: Perspectives on Polish Avant-Garde Film, 1916-1989. London: Wallflower Press, 144-145. 